Meta

Journal des traducteurs

Translators' Journal

\title{
Medical Interpreting in Canada's North
}

\section{Jacopoosie Peter}

Volume 38, numéro 1, mars 1993

La traduction et l'interprétation dans le nord du Canada

Translation and Interpretation in Northen Canada

URI : https://id.erudit.org/iderudit/003828ar

DOI : https://doi.org/10.7202/003828ar

Aller au sommaire du numéro

Éditeur(s)

Les Presses de l'Université de Montréal

ISSN

0026-0452 (imprimé)

1492-1421 (numérique)

Découvrir la revue

\section{Citer cet article}

Peter, J. (1993). Medical Interpreting in Canada's North. Meta, 38(1), 42-44.

https://doi.org/10.7202/003828ar

\section{Résumé de l'article}

On présente l'évolution du développement du système de soins de santé dans l'Arctique oriental canadien de la Deuxième Guerre mondiale à aujourd'hui. On expose certains des enjeux relatifs à la qualité des services d'interprétation médicale dans les Territoires du Nord-Ouest, comme par exemple l'âge de l'interprète et son niveau de compétence dans les deux langues. On traite aussi des problèmes liés à l'utilisation de la terminologie générale par rapport à la terminologie spécialisée. 


\title{
MEDICAL INTERPRETING IN CANADA'S NORTH
}

JACOPOOSIE PETER

Iqaluit, Northwest Territories, Canada

\begin{abstract}
Résumé
On présente l'évolution du développement du système de soins de santé dans l'Arctique oriental canadien de la Deuxième Guerre mondiale à aujourd' hui. On expose certains des enjeux relatifs à la qualité des services d' interprétation médicale dans les Territoires du Nord-Ouest, comme par exemple l'âge de l'interprète et son niveau de compétence dans les deux langues. On traite aussi des problèmes liés à l'utilisation de la terminologie générale par rapport à la terminologie spécialisée.
\end{abstract}

\begin{abstract}
This article provides some insight into the historical development of the health care system in Canada's Eastern Arctic from the Second World War to the present. It discusses some of the issues related to the quality of medical interpretation services in the NWT, such as the age of the interpreter and competence in both languages. A short discussion on the use of generalized versus specialized terminology is also included.
\end{abstract}

Before World War II there was little organized health care in Canada's Eastern Arctic. Most health services were provided by missionaries, who operated hospitals in Pangnirtung (Anglican - serving all of Baffin Island and most of the northern coast of Quebec) and in Chesterfield Inlet (Roman Catholic - serving the Keewatin, Melville Peninsula and parts of the Central Arctic). As well, government doctors and dentists made brief visits every summer during annual voyages of the Eastern Arctic Patrol.

Health conditions at this time were poor. Epidemics of contagious diseases like smallpox, influenza, pneumonia, typhoid fever, spinal meningitis and tuberculosis were causing the population to decline. Infant mortality rates were the highest in the world.

After World War II, the federal Department of Health and Welfare began to install a network of nursing stations throughout the Eastern Arctic to provide year-round health services. Large numbers of people were sent to hospitals in southern Canada, especially for the treatment of tuberculosis. By the end of 1956, nearly 10 percent of the total Canadian Inuit population were receiving treatment for tuberculosis in southern hospitals. This was a very frightening experience for many people, but the disease was eventually brought under control.

In 1969 the Department of Health and Welfare began to train native community health representative (CHR's) to help nursing station staff communicate with native people in the communities.

Until 1987, when health services in the NWT were finally devolved from the Federal Government to the Government of the Northwest Territories, northern people had very little influence over the quality of health care they were receiving. Today, community and regional health boards composed of people in the community meet regularly to discuss problems concerning health services.

There are still many unresolved issues. They include demands by Inuit women for community-based mid-wives, continuing problems with patients in hospitals in southern 
Canada, the almost complete lack of Inuit nurses and doctors, and the need to improve the quality of interpreting in the health care field.

The need to improve the quality of medical interpreting is difficult to resolve. The causes are complex and there is no short-term solution.

Many young interpreters spent much of their adolescence attending high school outside of their home communities, therefore not learning traditional skills such as hunting. This lack of traditional knowledge has major ramifications on their interpreting abilities, as they are unfamiliar with certain terminology areas. For example, younger interpreters who have lost their hunting skills did not learn animal anatomy and physiology and have problems with terminology other than basic organs.

This lack of knowledge can lead to problems in interpretation:

Qimirluga iluannittuq - The small of my back hurts.

In the above example the term qimirluga "the small of my back," would be unfamiliar to many young people today. Many of them would also be unaware of the distinction between such terms as taqaq (vein) and taqavik (artery) leading to mistranslations such as the following:

Taqatit qanuittuqtaqarmata - You have a problem with your arteries.

Another such example occurs in the following case where a doctor asked, "Are you feeling pain?" which was misinterpreted as "aanniqattaqpit?" ("Are you crying out in pain?") instead of "ippinniaqattaqpiit iluanngittumik?" ("Are feeling something uncomfortable?"). In this case, the elder in question was sent back to his home community without receiving proper treatment, which necessitated a further trip to hospital later.

Terminology related to minor internal organs such as pancreas, appendix, etc., causes problems, as do diseases and ailments related to these organs, such as gallstones.

Compounding the fact that many of these young interpreters have problems in Inuktitut terminology is the fact that they often lack high enough academic levels to interpret medicalese, often leading to paraphrases by medical personnel before an interpretation can occur. "Your test results show that you have angina", would need first to be paraphrased as, "Your test results show us that your arteries are blocked".

Many southern specialists unfamiliar with northern interpreters find it necessary to simplify their language more than they would working with French/English interpreters in southern Canada.

The lack of trained medical interpreters over time has also created an interesting dilemma relating to the language itself.

Although a lot of specialized language originally existed within the language, as demonstrated by the elders' knowledge of anatomy and physiology, much of this terminology has been lost in this present generation, leading to a tendency for generalized terminology to be widely used and accepted.

For example "You have bronchitis", has been interpreted as "Puvallukkavit" ("You have a problem with your lungs") instead of "Puvvirigavit".

As the use of generalized terminology has become widely accepted, when more specific terminology is used patients become unduly alarmed and believe that their ailment is more serious than when the general term is used.

What then should the interpreter do? The use of general terminology leads to language loss. The use of specialized terminology, once widely used, as demonstrated by the elders knowledge, would help to revitalize the language, but at the patients' expense. 
Few medical interpreters are over 45 years old, given that most older people are unilingual. Although older interpreters have a much greater command of Inuktitut, few have attended school and all have weak English skills, also leading to problems with interpretation.

The issues discussed above are compounded by the lack of dictionaries and resource materials available in Inuktitut.

The problems facing medical interpreters in the Arctic present a difficult challenge which will not be resolved in the near future. 